\title{
ORAL HEALTH KNOWLEDGE AMONG BRAZILIAN PRESCHOOLERS AND THEIR CARERS RECEIVING AND NOT RECEIVING HEALTH PROMOTION
}

\author{
CONHECIMENTO SOBRE SAÚDE BUCAL ENTRE PRÉ-ESCOLARES E SEUS \\ CUIDADORES QUE RECEBERAM E QUE NÃO RECEBERAM PROMOÇÃO DE \\ SAÚDE
}

\begin{abstract}
Paula Caetano ARAÚJO' ${ }^{1}$; Mario Vianna VETTORE ${ }^{2}$; Sarah R BAKER ${ }^{3}$; Cléa Adas Saliba GARBIN ${ }^{4}$; Suzely Adas Saliba MOIMAZ ${ }^{5}$; Renato Moreira ARCIERI ${ }^{6}$

1. Professor in Faculty of Dentistry, Federal University of Uberlândia, Unit of Social and Preventive Dentistry, Uberlândia, Minas Gerais State, Brazil. pcaraujo@ufu.br; 2. Senior Lecturer in Dental Public Health, Unit of Dental Public Health, School of Clinical Dentistry, University of Sheffield, Sheffield, South Yorkshire, UK; 3. Professor in Psychology and HPC registered Health Psychologist, Unit of Dental Public Health, School of Clinical Dentistry, University of Sheffield, Sheffield, South Yorkshire, UK; 4. Full Professor and vice-coordinator of Social and Preventive Dentistry Postgraduate Programme, Department of Infant and Social Dentistry, Araçatuba

Dental School, UNESP, Araçatuba, São Paulo State, Brazil; 5. Full Professor and coordinator of Social and Preventive Dentistry Postgraduate Programme, Department of Infant and Social Dentistry, Araçatuba Dental School, UNESP, Araçatuba, São Paulo State, Brazil; 6. Adjunct Professor, Department of Infant and Social Dentistry, Araçatuba Dental School, UNESP, Araçatuba, São Paulo State, Brazil.
\end{abstract}

\begin{abstract}
Few studies have evaluated oral health promotion (OHP) programs in nursery schools. This research aimed to assess whether there were differences in oral health knowledge between preschoolers and carers who received or did not receive an OHP program in nursery schools. A post-intervention observational study involving 5-6 years-old preschoolers and 169 carers was carried out in 10 nursery schools. The preschoolers in the OHP program group $(\mathrm{N}=93)$ received information on oral health and recreational activities relating to oral health, whereas in the control group $(\mathrm{N}=90)$, no OHP activity was provided. Children's age and sex, carer's age, child kinship, education and family income were collected via questionnaire. Children and carer's oral health knowledge scores were assessed through structured interviews. Independent variables were compared between groups by t-test, Chi-square and Mann-Whitney test. The association between children and carer's oral health knowledge and the OHP program group was tested using multivariate Poisson regression. Children's oral health knowledge was significantly associated with the OHP program group. Carer's oral health knowledge did not differ between intervention and control groups. Children attending nursery schools provided with OHP programs had greater oral health knowledge than those attending nursery schools without OHP activities.
\end{abstract}

KEYWORDS: Health Promotion. Oral Health. Child. Preschool

\section{INTRODUCTION}

Health promotion actions have been developed in school environments because the main environmental characteristics can be controlled, there is a established and planned learning infrastructure and there is an opportunity to strengthen relationships between carers, students and their parents (HALONEN et al., 2013). The school has an important role in developing a systematic and continuous environment for health promotion (HENDERSON; RUBIN, 2014) and also places together several students with similar ages where preventive health actions can be implemented (TAI et al., 2009).

Oral health education, contained within the oral health promotion context, incorporate healthy habits into preschoolers' daily routine. For example, supervised toothbrushing; the recreational activities on oral health promotion such as puzzles, hopscotch, puppets theater, workshops with drawings to paint and team games; the lectures on oral health and general hygiene help facilitate healthy habits (MOYSÉS, 2012). Furthermore, children are also highly prone to learn and assimilate behaviours and to build affective ties (AGRAWAL; PUSHPANJALI, 2011). The integrated health education and health promotion approach has shown positive results in terms of learning and maintaining new habits and attitudes of the community involved with these activities (SHARMA; ROMAS, 2008). The age group from four to seven years is considered an appropriate period for oral health promotion interventions, because children's behaviours are being established and they are able to develop hygiene and nutrition habits (BOURGEOIS; LLODRA, 2014).

The motivation and cooperation of children's parents and carers is essential to develop sucessful health promotion activities for this specific 
age group. Parents and carers should be involved in the health change since they have an important role to ensure the reformulation of health habits, to reinforce the health practices and, furthermore, to facilitate self-care (ARROW; RAHEB; MILLER, 2013).

The establishment of educational and preventive activities within child health promotion has been recommended due to the increased demand of health care by this age group and the lack of trained professionals, reflecting the need of health policies related to community characteristics (TINANOFF; KANELLIS; VARGAS, 2002). Thus, in recent years, oral health promotion programs in school environments have been implemented across different countries, targeting preschoolers and their parents or carers (BOURGEOIS; LLODRA, 2014), based on the Health Promoting Schools principles.

Most programs have emphasised the strengthening of community action and the development of personal skills; key aspects of the Ottawa Health Promotion Framework (SIMPSON; FREEMAN, 2004). However, few studies have evaluated the effectiveness of oral health promotion programs for preschoolers and their carers. The evaluation of health care programs is necessary in its own rights and can provide indicators of the quality of activities in practice (KAGEYAMA et al., 2014). The present study assessed an Oral Health Promotion (OHP) Program in nursery schools in Brazil. The specific aim being to examine whether there were differences in the oral health knowledge of preschoolers and their carers attending nurseries that received or did not receive an OHP program.

\section{MATERIAL AND METHODS}

\section{Ethical issues}

An information and consent form was sent to all carers asking for their participation and their child. The purpose of the investigation was explained to all preschoolers' carers within the schools. All who agreed provided written consent. The study was approved by the Research Ethics Committee of Araçatuba Dental School, Univ Estadual Paulista (Protocol no. FOA-283.017/2013).

\section{Study design and Sample characteristics}

A post-intervention comparative study was conducted to verify the effectiveness of the oral health promotion program through the preschooler and their carers. Preschoolers between 5 and 6 years old from 10 state-funded nursery schools and their carers were recruited in 2013, in the city of Araçatuba, São Paulo State, Brazil.
Araçatuba is located at the northwest region of São Paulo State, Brazil. It has a population of 191,662 inhabitants (INSTITUTO BRASILEIRO DE GEOGRAFIA E ESTATÍSTICA, 2014); 2,937 of which attended nursery schools (INSTITUTO BRASILEIRO DE GEOGRAFIA E ESTATÍSTICA, 2012). The municipal Human Development Index is 0.788 in 2010 (IBGE, 2010), with $16.2 \%$ of poverty and a Gini index of 0.47 (INSTITUTO BRASILEIRO DE GEOGRAFIA E ESTATÍSTICA, 2003). Violence in Araçatuba is higher than the state capital with a homicide rate around 20 per 100,000 inhabitants (WAISELFISZ, 2012).

Participants were preschoolers in the last stage of nursery school and their carers. They were invited once. All carers of children aged 5-6 years $(\mathrm{N}=232)$ were invited for the study. Of them, 183 agreed for their child participation $(78.8 \%$ response rate) and 169 carers returned the questionnaires ( $72.8 \%$ response rate).

\section{Selection of nursery schools}

The city of Araçatuba has 35 stated-funded nursery schools (INSTITUTO BRASILEIRO DE GEOGRAFIA E ESTATÍSTICA, 2012). The OHP program of Araçatuba Dental School visits 5 statedfunded nursery schools over a period of 6 months following which, it moves to 5 new stated-funded nursery schools. The schools from the intervention group were the last ones visited by the program in the first semester of 2013. The control group comprised state-funded nursery schools in the same city that had not received the program. The control nursery schools were selected based on the placement of the intervention group. That is, each school from the intervention group had a control group school within the same neighborhood.

\section{Groups of Comparison}

Two groups were formed. The intervention group consisted of preschoolers that were fully registered in 5 nursery schools that received the oral health promotion program for at least 6 months. The control group consisted of preschoolers fully registered in 5 nursery schools that never received the program.

The data was collected by a single trained interviewer (PCA). The interviews were carried out in a private room at the nursery school where the children were asked to choose from a list of drawings which one they considered "good" for their teeth. A self-administered questionnaire was sent to each carer by the school's office when they collected their children at the nursery school. The 
carer's questionnaire was requested to be returned to the school's office within 2 weeks. The data collection occurred between April and August 2013.

\section{Pilot study}

A pilot study was conducted in two nonselected nursery schools in the same city using the same criteria for the main study. On the basis of the pilot study, the assessment of preschoolers's oral health knowledge was modified. In the pilot, they were asked to draw the figures, which proved difficult due to their age and ability to write. Thus, in the main study they were asked to identify the drawings associated with the health of their teeth. The carer's assessment did not need to be modified as a result of the pilot.

\section{Oral health promotion activities}

The oral health promotion activities were delivered weekly during a 6 month period. Every school in the intervention group received 24 visits (nearly 90 minutes of duration each session) during the 6 months that the oral health promotion program stayed at the school.

Before delivering the program, academic staff and graduate dental school students discussed the oral health promotion activities, the approach that should be carried out with the children, the best way to use the supporting materials and to discuss all the topics that were going to be addressed with the children, carers and school teaching staff. These meeting groups took place every two months during the program.

Initially, undergraduate and postgraduate dental students visited the nursery school to plan the oral health activities according to a pre-specified plan. The plan aimed to organize the activities so that the visit would include the highest number of children as possible. Each visit involved at least two classrooms of 15 preschoolers. In this way, all classrooms were fully visited within a month of activities. Each child attended at least $90 \%$ of the education sessions. The recreational activities on oral health promotion, the lectures on oral health and general hygiene and the supervised toothbrushing were undertaken in each visit. The program team was split into small groups which rotated around the children during these three activities in order to make sure all children received all of the program activities (see Table 1).

Table 1. The Oral Health Promotion activities of Araçatuba Dental School related to the Ottawa Charter.

Oral Health Promotion Program Activities

\begin{tabular}{|c|c|c|}
\hline Activities & Aim & Ottawa Charter \\
\hline $\begin{array}{l}\text { The program empowers the } \\
\text { undergraduate students that are going } \\
\text { to undertake the oral health } \\
\text { promotion activities through meeting } \\
\text { groups. }\end{array}$ & $\begin{array}{l}\text { To discuss the approach that should } \\
\text { be carried out with the children. } \\
\text { To show the best way to use the } \\
\text { supporting materials. } \\
\text { To debate all the topics that are going } \\
\text { to be addressed. } \\
\text { To train the undergraduates for the } \\
\text { public health activities. }\end{array}$ & $\begin{array}{l}\text { Developing personal skills. } \\
\text { Strengthening community } \\
\text { action. } \\
\text { Reorienting health services. }\end{array}$ \\
\hline $\begin{array}{l}\text { Initial visits at the state funded } \\
\text { nursery schools, before the activities } \\
\text { begin. }\end{array}$ & $\begin{array}{l}\text { To plan the activities according to the } \\
\text { availability of the infrastructure } \\
\text { offered. } \\
\text { To allow the team to think about what } \\
\text { need to be modified at the nursery } \\
\text { school environment. } \\
\text { To give the team the possibility to } \\
\text { know the teaching staff and the } \\
\text { children. } \\
\text { To strengthen ties between the } \\
\text { community and the university. } \\
\text { To establish emotional bonds. }\end{array}$ & $\begin{array}{l}\text { Creating } \\
\text { environments. }\end{array}$ \\
\hline $\begin{array}{l}\text { Recreational activities on oral health } \\
\text { promotion for the preschoolers. }\end{array}$ & $\begin{array}{l}\text { To develop children's cognitive } \\
\text { ability. } \\
\text { To conduct preventive practices in } \\
\text { oral and systemic health. } \\
\text { To turn the children in a multiplier of }\end{array}$ & $\begin{array}{l}\text { Developing personal skills. } \\
\text { Strengthening community } \\
\text { action. }\end{array}$ \\
\hline
\end{tabular}


oral health.

To establish emotional bonds.

Lectures on oral health and general To prevent oral and systemic Developing personal skills. hygiene for the preschoolers. diseases.

To incorporate preventive practices and healthy habits.

To establish emotional bonds.

\begin{tabular}{|c|c|c|}
\hline $\begin{array}{l}\text { Supervised toothbrushing for the } \\
\text { preschoolers. }\end{array}$ & $\begin{array}{l}\text { To provide dental plaque control. } \\
\text { To prevent oral diseases. } \\
\text { To improve the toothbrush ability. } \\
\text { To aware about the benefits of a good } \\
\text { toothbrushing. } \\
\text { To turn the children in a multiplier of } \\
\text { oral health. } \\
\text { To establish emotional bonds. }\end{array}$ & Developing personal skills. \\
\hline Warnings in the students' journal. & $\begin{array}{l}\text { To aware the carer that his child } \\
\text { needs dental treatment. } \\
\text { To follow-up the preschooler in order } \\
\text { to verify if he is receiving dental } \\
\text { treatment. }\end{array}$ & Developing personal skills. \\
\hline $\begin{array}{l}\text { Development of brush holders by the } \\
\text { undergraduate students. }\end{array}$ & $\begin{array}{l}\text { To provide a proper storage of the } \\
\text { toothbrushes. }\end{array}$ & $\begin{array}{l}\text { Developing personal skills. } \\
\text { Creating } \\
\text { environments. }\end{array}$ \\
\hline Lectures targeted to the carers. & $\begin{array}{l}\text { To develop knowledge about oral } \\
\text { health issues related to the children } \\
\text { and to the self-care. } \\
\text { To prevent oral and systemic } \\
\text { diseases. } \\
\text { To incorporate preventive practices } \\
\text { and healthy habits. }\end{array}$ & $\begin{array}{l}\text { Developing personal skills. } \\
\text { Strengthening community } \\
\text { action. }\end{array}$ \\
\hline $\begin{array}{l}\text { Lectures targeted to the teaching } \\
\text { staff. }\end{array}$ & $\begin{array}{l}\text { To develop knowledge about oral } \\
\text { health issues related to the children } \\
\text { and to the self-care. } \\
\text { To prevent oral and systemic } \\
\text { diseases. } \\
\text { To incorporate preventive practices } \\
\text { and healthy habits. } \\
\text { To enhance the trust bonds between } \\
\text { the teacher and the preschooler. }\end{array}$ & $\begin{array}{l}\text { Developing personal skills. } \\
\text { Strengthening community } \\
\text { action. }\end{array}$ \\
\hline
\end{tabular}

\section{Recreational activities}

The recreational activities related to oral health included fitting figures, puzzles, hopscotch, tunnel, baskets of the happy and sad tooth, puppet theatre, fishing, workshops with drawings to paint, puppets and team games.

\section{Lectures on general and oral health self- care}

The lectures on oral health care involved toothbrushing and use of dental floss, emphasizing the need of parental or carer's home supervision. The lectures also covered nutritional issues, nonnutritive sucking habits and the process of dental caries. In relation to general hygiene, the topics covered hair and nail care, handwashing, baths and clothing.

\section{Supervised toothbrushing}

The supervised toothbrushing was based on Fone's brushing method (FONES, 1934) and was carried out by one team member assisting one child at a time. Plaque disclosing and dental macromodels were used to support this activity.

On average, $90 \%$ of the teachers and $50 \%$ of the parents/carers also attended the sessions about oral health issues related to children and to their self-care as part of the planned activities in each intervention school. They occurred every two months (one hour each session) at the nursery school. 
Brush holders were made by the undergraduates dental students in all classrooms and renewed twice a year. Further details of the program can be seen in Table 1 .

\section{Measures}

\section{Child}

A questionnaire containing 12 images was used to assess children's oral health knowledge (FREIRE; SOARES; PEREIRA, 2002). The preschoolers were asked to choose the images that they considered "good" for their teeth. The question used was "Mark with an "X" which image is good for your teeth". Of the 12 images, four were related to healthy oral habits, including toothpaste; dental floss; dentist; toothbrush. The eight remaining were sweets; candies and lollipops; popcorn; soft drinks; finger sucking; and sandwich, classified as dental unhealthy pictures. Each correct answer was registered as " 1 " point and the final score could range from 0 to 12 points. The more correct answers the higher the oral health knowledge score. Children's age and sex were also registered.

\section{Parents / Carers}

The questionnaire to assess parents/carers oral health knowledge was based on the work of Vasconcelos et al. (2001) and Santos (2009). The carers were asked to inform their age, kinship with the preschooler, schooling, family income, self-rated oral health, perception of their child oral health and knowledge on oral health habits.

Self-rated oral health and the perception of their child's oral health was assessed using a 5 point scale (very poor; poor; regular; good; very good). Four items were used to evaluate their knowledge on oral health habits (toothbrush; toothpaste; dental floss and mouthwash). Frequency of toothbrushing and frequency of toothpaste use: (1) once a day, (2) 2 times a day and (3) 3 or more times a day), frequency of dental floss and mouthwash (1) none; (2) once a day, (3) 2 times a day; (4) 3 or more times a day) was also evaluated. The final score varied from 4 to 14 . The higher the score the higher the oral health knowledge of the carers.

Parents and carers from the intervention group were also asked if they knew about the oral health activities at the nursery schools and the importance of the program. They were also evaluated on whether they had learnt about oral health with their children and if there had been any change in the family's oral habits. For these questions, the carers choose "yes" or "no" and explained their chosen option. These explanations were categorized based on Bardin technique (BARDIN, 2011) and then, quantified.

\section{Data analysis}

The normal distributions of continuous variable were tested by Kolmogorov-Smirnov test. Continuous variables were compared between intervention group and control group using MannWhitney test. Categorical data were analysed by Chi-square test. The association between the intervention group and control was tested through multivariate Poisson regression analysis to adjust for potential confounders. All covariates with $\mathrm{P}$ value < 0.10 in bivariate analysis were selected for multivariate analysis. All tests were performed using the program SPSS 22.0 (IBM Corporation, NY, USA). The significance level established for multivariate analysis was $5 \%(\mathrm{P}<0.05)$.

\section{RESULTS}

The final sample consisted of 93 preschoolers that received the oral health promotion program and their carers $(\mathrm{n}=85)$, and 90 preschoolers and their carers who did not receive the program $(\mathrm{n}=84)$. The mean age of the preschoolers was $5.62 \pm 0.49$ years old and $54.1 \%$ of the sample was female. The mean oral health knowledge score for the children was significantly higher in the intervention group, scoring 11.62, with the control group scoring $8.42(p<0.001)$ (Table 2$)$.

Table 2. Demographic and socioeconomic characteristics of the sample according to groups.

\begin{tabular}{lllll}
\hline & $\begin{array}{l}\text { Intervention } \\
\text { Group }\end{array}$ & Control group & Total & P-value \\
\hline $\begin{array}{l}\text { Children } \\
\text { Age, mean (SD) }\end{array}$ & $(\mathrm{N}=93)$ & $(\mathrm{N}=90)$ & $(183)$ & \\
$\begin{array}{l}\text { Sex, n (\%) } \\
\quad \text { Female }\end{array}$ & $5.65(0.48)$ & $5.60(0.49)$ & $5.62(0.49)$ & $0.53^{\text {a }}$ \\
$\quad$ & & & $0.616^{{ }^{b}}$ \\
$\begin{array}{l}\text { Male knildren knowledge } \\
\text { oral health, mean (SD) }\end{array}$ & $53(55.9)$ & $47(52.2)$ & $99(54.1)$ & \\
\hline
\end{tabular}




\begin{tabular}{|c|c|c|c|c|}
\hline Careers & $(\mathrm{N}=85)$ & $(\mathrm{N}=84)$ & $(183)$ & \\
\hline Age, mean (SD) & $33.25(8.88)$ & $33.10(7.96)$ & $33.18(8.42)$ & $0.909^{\mathrm{a}}$ \\
\hline Child kinship, n (\%) & & & & 0.358 \\
\hline Mother & $70(82.4)$ & $75(89.3)$ & $145(85.5)$ & \\
\hline Father & $8(9.4)$ & $6(7.1)$ & $14(8.3)$ & \\
\hline Other & $7(8.2)$ & $3(3.6)$ & $10(5.9)$ & \\
\hline Schooling, $\mathrm{n}(\%)$ & & & & $0.921^{\mathrm{b}}$ \\
\hline$<8$ years & $13(16.3)$ & $15(19.7)$ & $28(17.1)$ & \\
\hline $8-12$ years & $52(65.0)$ & $55(65.5)$ & $107(65.2)$ & \\
\hline$>12$ years & $15(18.8)$ & 14 (16.7) & $29(17.7)$ & \\
\hline Family income, $\mathrm{n}(\%)$ & & & & $0.862^{b}$ \\
\hline$\leq 2 \mathrm{BMW}$ & $36(55.4)$ & $39(57.4)$ & $75(56.4)$ & \\
\hline$>2 \mathrm{BMW}$ & $29(44.6)$ & $29(42.6)$ & $58(43.6)$ & \\
\hline Self-rated oral health, $\mathrm{n}(\%)$ & & & & $0.403^{b}$ \\
\hline Regular/Poor/Very Poor & $25(30.5)$ & $29(36.7)$ & $54(33.5)$ & \\
\hline Good/Very Good & $57(69.5)$ & $50(63.3)$ & $107(66.5)$ & \\
\hline $\begin{array}{l}\text { Perception of child's oral } \\
\text { health, } \mathrm{n}(\%)\end{array}$ & & & & $0.733^{b}$ \\
\hline Regular/Poor/Very Poor & $26(32.1)$ & $23(29.1)$ & $49(30.6)$ & \\
\hline Good/Very Good & $55(68.9)$ & $56(70.9)$ & $111(69.4)$ & \\
\hline
\end{tabular}

${ }^{\mathrm{a}} \mathrm{P}$-valor refers to t-test

${ }^{\mathrm{b}} \mathrm{P}$-valor refers to Chi-square-test

The mean age of the carers was $33.18 \pm 8.42$ years and $85.5 \%$ of them were the mothers of the children. $65.2 \%$ of the carers had between 8 and 12 years of schooling. The majority of the participants $(56.4 \%)$ has a family income lower than 2 Brazilian minimum wages $(\mathrm{BMW})$ (eq. $2 \mathrm{BMW}=£ 335$ ). $66.5 \%$ of the sample rated their own oral health as being good and/or very good. In relation to their children's oral health, $69.4 \%$ of the participants believed that their children had good and/or very good oral health. The score on oral health habits for the intervention group was 8.09 and for the control group 7.90. The carer's scores on oral health knowledge did not statistically differ between for intervention and control groups $(p=0.534)$.

Multivariate Poisson regression was used to test the association between all independent variables with the score of the children's oral health knowledge. Independent variables that presented significance at $20 \%(p<0.20)$ were retained in the analysis for adjustment (Table 3).

Table 3. Multivariate Poisson regression for the children's knowledge on oral health.

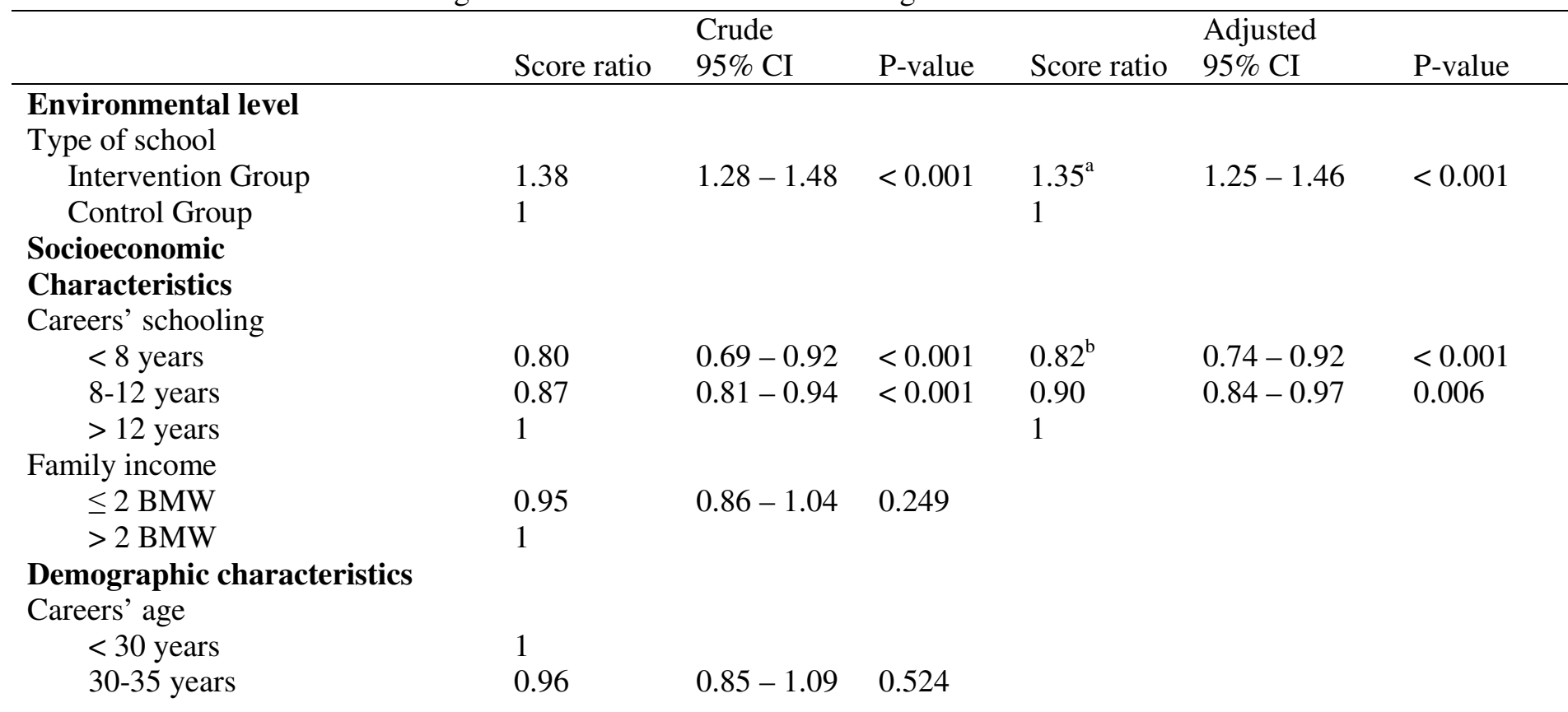




$$
\geq 36 \text { years }
$$

$$
0.97-1.17 \quad 0.175
$$

Child kinship

Other

Mother

1

Father

Children's age

5 years

6 years

1

Children's gender

Male

1

Female

$0.91-1.06 \quad 0.702$

${ }^{a}$ A child from the intervention group is expected to score, on average, 1.35 more times (or $35 \%$ higher) than a child from the control group; ${ }^{\mathrm{b}}$ The carers with 8 years or less of schooling level is expected to score, on average, 0.82 less times than the carers with 2 years or more of schooling level. BMW=Brazilian Minimum wage

The preschoolers from the intervention group were 1.35 times (or $35 \%$ higher) more likely to achieve a better score on the Child's measure of oral health knowledge compared with those from the control group (Table 4).

\begin{tabular}{|c|c|c|c|c|}
\hline & $\begin{array}{l}\text { Intervention } \\
\text { Group }\end{array}$ & Control group & Total & P-value \\
\hline $\begin{array}{l}\text { Children knowledge on } \\
\text { oral health, mean (SD) }\end{array}$ & $\begin{array}{l}(\mathrm{N}=93) \\
11.62(1.00)\end{array}$ & $\begin{array}{l}(\mathrm{N}=90) \\
8.42(2.90)\end{array}$ & $\begin{array}{l}(183) \\
10.05(2.68)\end{array}$ & $<0.001$ \\
\hline $\begin{array}{l}\text { Careers knowledge on oral } \\
\text { health, mean (SD) }\end{array}$ & $8.09(2.53)$ & $7.90(2.51)$ & $8.00(2.51)$ & 0.534 \\
\hline
\end{tabular}

Table 4. Comparison of scores on knowledge of oral habits between groups.

The carers with less than 8 years of schooling level were 0.82 less likely to achieved a better score at the Carer's measure in comparison with the carers with more than 12 years of schooling level.

For the questions exclusively applied to the carers from the intervention group, $94.2 \%$ of the carers reported that their children received guidance in relation to oral health promotion at the nursery school. 51.7\% informed that these activities were important to prevent disease and promote health. $75.2 \%$ said that they have already learned something about oral health with their child. The toothbrush and the use of dental floss were the most mentioned activities learned (47\%). $64.7 \%$ said that there were changes in the oral health habits because of the oral health promotion program. The oral and general hygiene were the habits mostly modified $(30.5 \%)$.

\section{DISCUSSION}

The key findings indicate that the Oral Health Promotion (OHP) program was associated with greater oral health knowledge of children but not warning their parent/carer's oral health knowledge.

Our results are in accordance with previous research showing that oral health promotion interventions developed in health promoting environments can build up new knowledge in young children (ARROW; RAHEB; MILLER, 2013; GIBBS et al., 2015; WATT; SHEIHAM, 1999). However, no significant differences in carer's knowledge was found; even though they reported changes in oral health habits at home after the programme period (HENDERSON; RUBIN, 2014).

The study of Santos, Garbin and Garbin (2012) also showed that the participants had learned something related to oral health with their child, as well as the identification of changes in their oral health family habits.

The Health Promoting Schools emerged as a successful strategy to improve health, oral health and health literacy (LEE, 2009). This is based on the fact that schools have an appropriate environment to develop children's skills and health behaviours. The OHP activities can be introduced into the school's curriculum. 
The repeated contact with the Araçatuba Dental School team as well as the combination of different types of activities during the oral health sessions may explain children's oral health knowledge in the intervention group.

The actions of the OHP programme could have developed the personal skills of the children (e.g. lectures on oral health and general hygiene for the preschoolers; supervised toothbrushing; warnings in the students' journal), strengthened community actions (e.g. empowerment of the undergraduate students that undertake the OHP activities; recreational activities on oral health promotion; lectures targeted to the carers and the teaching staff) and created supportive environments (e.g. initial visits at the state funded nursery schools; development of brush holders) in line with the principles of the Ottawa Charter. It has been shown that health teams that are in regular contact with the community can improve the efficiency of health promotion interventions, facilitating the empowerment related to individual's health (ARORA et al., 2010).

The lack of difference between the intervention and control groups in carers' oral health knowledge may suggests that the oral health promotion program could increase the frequency of activities related specifically to the carers in order to get them more involved and feeling part of the oral health program. As most of the schools that participated in the OHP programme were in deprived areas with high levels of poverty, it was difficult to facilitate the carer's engagement in the schools activities proposed. This has been posed as a challenge that needs to be addressed in the development of future health promoting programs in this area.

This is particularly relevant since early childhood is a crucial period in a child's development and this is acknowledged by the different professionals involved in the care of children's development (PHILLIPS; SHONKOFF, 2000). Studies on the evaluation of oral health promotion activities within nursery schools are scarce. However, Nowak and Casamassimo (1995) suggest that there are a number of benefits of early oral health guidance for preschool children.

The home environment of a preschooler is also essential for the reinforcement of activities learned within a school-based health promotion program. Thus, it is important to motivate their parents or carers, allowing them support and reinforce their children's daily oral health habits obtained through the school's activities (ARROW; RAHEB; MILLER, 2013).
It is important to highlight that the present study is part of a research project that also evaluated, in a comparative way, the teaching staff of the participating nursery schools. The same nursery schools were used for all the subjects involved in the research, in order to reach all the social actors involved in the school environment. The chi-square test was applied, however it was not possible to verify statistically significant differences between the teaching staff groups that received and not received the oral health promotion program of Araçatuba Dental School (ARAÚJO et al., 2017).

\section{Limitations}

Our findings cannot be generalized to different places and other age groups because this study included preschoolers aged 5-6 years old from state funded nursery schools who were exposed to specific OHP activities planned by the Araçatuba Dental School. It would however be interesting to evaluate and compare similar dental outreach programs conducted with a similar purpose from other areas in Brazil or developed in other countries.

The lack of trained personnel (postgraduates and undergraduates students, and volunteers) limited the program to achieve a greater number of nursery schools. It also identified some conflicts related to the school schedule and the priorities that the coordination of the nursery schools had during the OHP activities. Some nursery school teachers did not engage with the activities even though they were requested to do so, perhaps decreasing the preschoolers motivation.

Sometimes the OHP activities were not feasible due to the poor infrastructure of some nursery schools. Therefore, the school's environment had to be modified and part of the activities adjusted to promote oral health. The postintervention study design has also been recognized as a limitation and longitudinal studies on this topic are needed. The use of other outcome measures to assess oral health knowledge of the carers should also be considered.

\section{Implications for future research}

Future studies are needed to evaluate the effectiveness of the oral health program using a more comprehensive approach, including the use of children's dental clinical measures (e.g. Decayed, missing and field teeth - DMFT) and children's oral health related quality of life (e.g. Child Perceptions Questionnaire - CPQ) over time in response to the intervention. In addition, more detailed analysis needs to be undertaken on the process; that is, which activities are most beneficial for children's oral 
health within the program and why. Finally, the program needs to be further developed in order to facilitate the inclusion and increase the motivation of the carers and teachers into the intervention activities and the transmission of oral health habits into the wider school as well as to the home environment.

\section{CONCLUSION}

Children attending nursery schools where OHP programs were provided had greater oral health knowledge than those attending nursery schools without OHP activities. Carer's oral health knowledge did not differ between intervention and control groups.

\section{ACKNOWLEDGMENTS}

The authors would like to thank CAPES Foundation (Coordination for the Improvement of Higher Level Personnel), Ministry of Education of Brazil, for financial support for this study through a doctorate 'sandwich' scholarship (Process n. 3124/14-2). Also thanks to The University of Sheffield for hosting the visiting scholarship of the primary author and to all staff of the School of Clinical Dentistry - University of Sheffield.

RESUMO: Introdução. Poucos estudos avaliaram os programas de promoção em saúde bucal (PSB) em préescolas. Objetivo. Essa pesquisa objetivou avaliar se houve diferenças no conhecimento de saúde bucal entre pré-escolares e seus cuidadores que receberam e que não receberam o programa de PSB no ambiente escolar. Métodos. Este estudo observacional retrospectivo envolveu pré-escolares, de 5 a 6 anos, e 169 cuidadores, pertencentes a 10 Escolas Municipais de Educação Básica. Os pré-escolares pertencentes ao grupo do programa de PSB $(\mathrm{n}=93)$ receberam informações e atividades recreativas relacionadas à saúde bucal, enquanto que, no grupo controle $(\mathrm{n}=90)$, nenhuma atividade de promoção em saúde foi fornecida. As informações sobre idade, sexo, idade dos cuidadores, grau de parentesco, escolaridade, renda familiar foram coletadas através de questionário. O conhecimento sobre saúde bucal das crianças e cuidadores foram colhidos por meio de entrevistas estruturadas. As variáveis independentes foram comparadas entre grupos através do teste-T, Qui-quadrado e Mann-Whitney. Foi utilizado o modelo multivariado de regressão de Poisson com a finalidade de identificar a associação da aplicação do programa de PSB com o conhecimento de saúde bucal dos pré-escolares e seus cuidadores. Resultados. O conhecimento em saúde bucal das crianças foi significativamente maior no grupo que recebeu as atividades do programa. O conhecimento em saúde bucal dos cuidadores não diferiu entre os grupos intervenção e controle. Conclusões. As crianças que pertenciam às escolas que receberam o programa de PSB possuíam maior conhecimento em saúde bucal do que aquelas alocadas em escolas sem as atividades do programa.

PALAVRAS-CHAVE: Promoção da Saúde. Saúde Bucal. Pré-Escolar

\section{REFERENCES}

AGRAWAL, N.; PUSHPANJALI, K. Feasibility of including APF gel application in a school oral health promotion program as a caries-preventive agent: a community intervention trial. Journal of Oral Science, Tokio, v. 53, n. 2, p. 185-191, jun. 2011. https://doi.org/10.2334/josnusd.53.185

ARAÚJO, P. C.; GARBIN, C. A. S.; MOIMAZ, S. A. S.; SALIBA, N. A.; REATTO, D.; ARCIERI, R. M. Evaluación comparativa del conocimiento sobre salud oral entre equipos pedagógicos que recibieron y no recibieron promoción en salud. International Journal of Odontostomatology, Temuco, v. 11, n. 2, p. 198206, jun. 2017. https://doi.org/10.4067/S0718-381X2017000200013

ARORA, M.; TEWARI, A.; TRIPATHY, V.; NAZAR, G. P.; JUNEJA, N. S.; RAMAKRISHNAN, L.; REDDY, K. S. Community based model for preventing tobacco use among disadvantaged adolescents in urban slums of India. Health Promotion International, Oxford, v. 25, n. 2, p. 143-152, jun. 2010. https://doi.org/10.1093/heapro/daq008

ARROW, P.; RAHEB, J.; MILLER, M. Brief oral health promotion intervention among parents of young children to reduce early childhood dental decay. BMC Public Health, London, v. 13, p. 245, 2013. https://doi.org/10.1186/1471-2458-13-245 
BARDIN, L. Content Analysis. São Paulo: Edições 70, 2011.

BOURGEOIS, D. M.; LLODRA J. C. Global burden of dental condition among children in nine countries participating in an international oral health promotion programme, 2012-2013. International Dental Journal, London, v. 64, n. 2, p. 27-34, oct. 2014. https://doi.org/10.1111/idj.12129

FONES, C. A. Mouth hygiene. Phyladelphia: Lea \& Febiger, 1934.

FREIRE, M. M.; SOARES, F. F.; PEREIRA, M. F. Conhecimentos sobre saúde dental, dieta e higiene bucal de crianças atendidas pela Faculdade de Odontologia da Universidade Federal de Goiás. Jornal Brasileiro de Odontopediatria \& Odontologia do Bebê, Curitiba, v. 5, n. 25, p. 195-199, maio/jun. 2002.

GIBBS, L.; WATERS, E.; CHRISTIAN, B.; GOLD, L.; YOUNG, D.; DE SILVA, A.; CALACHE, H.; GUSSY, M.; WATT, R.; RIGGS, E.; TADIC, M.; PRADEL, V.; HALL, M.; GONDAL, I.; MOORE, L. Teeth Tales: a community based child oral health promotion trial with migrant families in Australia. BMJ Open, London, v. 5, n. 6, p. 1-12, 2015. https://doi.org/10.1136/bmjopen-2014-007321

HALONEN, H.; PESONEN, P.; SEPPÄ, L.; PELTONEN, E.; TJÄDERHANE, L.; ANTTONEN V. Outcome of a community-based oral health promotion project on primary schoolchildren's oral hygiene habits.

International Journal of Dentistry, Cairo, v. 2013, p. 1-6, 2013. https://doi.org/10.1155/2013/485741

HENDERSON, E.; RUBIN, G. A model of roles and responsibilities in oral health promotion based on perspectives of a community-based initiative for pre-school children in the U.K. British Dental Journal, London, v. 216, n. 5 , p. E11, mar. 2014. https://doi.org/10.1038/sj.bdj.2014.196

INSTITUTO BRASILEIRO DE GEOGRAFIA E ESTATÍSTICA. IBGE 2014: censo demográfico. Brasília, Brazil. 2014. Disponível em: <http://www.ibge.gov.br/home>. Acesso em: 10 maio 2017.

INSTITUTO BRASILEIRO DE GEOGRAFIA E ESTATÍSTICA. IBGE 2012: censo demográfico. Brasília, Brazil. 2012. Disponível em: <http://www.ibge.gov.br/home>. Acesso em: 10 maio 2017.

INSTITUTO BRASILEIRO DE GEOGRAFIA E ESTATÍSTICA. IBGE 2010: censo demográfico. Brasília, Brazil. 2010. Disponível em: <http://www.ibge.gov.br/home>. Acesso em: 10 maio 2017.

INSTITUTO BRASILEIRO DE GEOGRAFIA E ESTATÍSTICA. IBGE 2003: censo demográfico. Brasília, Brazil. 2003. Disponível em: <http://www.ibge.gov.br/home>. Acesso em: 10 maio 2017.

KAGEYAMA, M.; ODAGIRI, K.; SUZUKI, N., HONDA, K.; ONOUE, K.; YAMAMOTO, M.; MIZUTA, I.; UEHARA, A. Educational effectiveness of a group health education program in the workplace and an examination of educational methods to promote behavior modification. Sangyo Eiseigaku Zasshi, Tokio, v. 56, n. 5, p. 141-151, 2014. https://doi.org/10.1539/sangyoeisei.E13002

LEE, A. Health-promoting schools: evidence for a holistic approach to promoting health and improving health literacy. Applied Health Economics and Health Policy, Auckland, v. 7, n. 1, p. 11-17, 2009. https://doi.org/10.1007/BF03256138

MOYSÉS, S. J. Inequalities in oral health and oral health promotion. Brazilian Oral Research, São Paulo, v. 26, n. 1, p. 86-93, 2012. https://doi.org/10.1590/S1806-83242012000700013

NOWAK, A. J.; CASAMASSIMO, P. S. Using anticipatory guidance to provide early dental intervention. Journal of the American Dental Association, Chicago, v. 126, n. 8, p. 1156-1163, aug. 1995. https://doi.org/10.14219/jada.archive.1995.0337

PHILLIPS, D. A.; SHONKOFF, J. P. From neurons to neighborhoods: the science of early childhood development. Washington: National Academy Press, 2000. 
SANTOS, K. T. Oral health education at school: an analysis of the subjects involved in the process. 2009. 140 f. Tese (Doutorado) - Faculdade de Odontologia de Araçatuba, Universidade Estadual Paulista, Araçatuba 2009.

SANTOS, K. T.; GARBIN, A. J. I.; GARBIN, C. A. S. Saúde bucal nas escolas: relato de experiência. Revista Ciência em Extensão, São Paulo, v. 8, n. 1, p. 161-169, 2012.

SHARMA, M.; ROMAS, J. A. Theoretical foundations of health education and health promotion. Manoj Sharma: Jones and Barlett Publishers, 2008.

SIMPSON, K.; FREEMAN, R. Critical health promotion and education--a new research challenge. Health Education Research, Oxford, v. 19, n. 3, p. 340-348, jun. 2004. https://doi.org/10.1093/her/cyg049

TAI, B. J.; JIANG, H.; DU, M. Q.; PENG, B. Assessing the effectiveness of a school-based oral health promotion programme in Yichang City, China. Community Dentistry and Oral Epidemiology, Copenhagen, v. 37, n. 5, p. 391-398, oct. 2009. https://doi.org/10.1111/j.1600-0528.2009.00484.x

TINANOFF, N.; KANELLIS, M. J.; VARGAS, C. M. Current understanding of the epidemiology mechanisms, and prevention of dental caries in preschool children. Pediatric Dentistry, Chicago, v. 24, n. 6, p. 543-551, nov./dec. 2002.

VASCONCELOS, R.; MATTA, M. L.; PORDEUS, I. A.; PAIVA, S. M. Escola: um espaço importante de informação em saúde bucal para a população infantile. Pós-Graduação em Revista, São José dos Campos, v. 4, n. 3, p. 43-48, set./dez. 2001.

WAISELFISZ, J. J. Mapa da Violência 2012. Os novos padrões da violência homicida no Brasil. São Paulo, Brazil. 2012. Disponível em: <http://www.mapadaviolencia.org.br/pdf2012/mapa2012_web.pdf>. Accesso em: 10 maio 2017.

WATT, R.; SHEIHAM, A. Inequalities in oral health: a review of the evidence and recommendations for action. British Dental Journal, London, v. 187, n. 1, p. 6-12, jul. 1999. https://doi.org/10.1038/sj.bdj.4800191 https://doi.org/10.1038/sj.bdj.4800191a 